\title{
Sistem "full pre trial disclosure" dalam penegakan asas peradilan sederhana, cepat dan biaya ringan
}

\author{
Wika Yudha Shanty
}

Wika Yudha Shanty; Fakultas Hukum Universitas Merdeka Malang; Jl. Terusan Raya Dieng Nomor 62-64; Malang; 65146; Jawa Timur; Indonesia.

\begin{tabular}{l} 
A R T I C L E I N F O \\
\hline Article history: \\
Received 2020-10-11 \\
Received in revised form \\
2020-11-20 \\
Accepted 2020-12-01
\end{tabular}

Kata kunci:

Asas Hukum; Pengadilan;

Peradilan.

Keywords:

Legal Principles; Court, Judiciary.

DOI: https://doi.org/10.26905/

idjch. v11i3. 5473.

\section{How to cite item:}

Shanty, W. Y. (2020). Sistem

"full pre trial disclosure" dalam penegakan asas peradilan sederhana, cepat, dan biaya ringan. Jurnal Cakrawala Hukum, 11(3). 271-281. doi:10.26905/ idjch.v11i3.5473.
Corresponding Author:

* Wika Yudha Shanty.

E-mail address: wika.yudha@unmer.ac.id

\begin{abstract}
Abstrak
Asas hukum sebagai norma dasar yang dijabarkan sebagai dasar/petunjuk umum bagi hukum positifl hukum yang berlaku. Salah satu permasalahan asas hukum yang akan dibahas oleh peneliti dalam penelitian kali ini adalah tentang penerapan asas yang tidak sesuai dengan kenyataan yang terjadi di pengadilan. Terlalu banyak formalitas yang sulit untuk dipahami, dan peraturan-peraturan yang tidak jelas, sehingga memungkinkan timbulnya berbagai penafsiran dan mengakibatkan ketakutan untuk beracara di pengadilan. Terlalu banyak formalitas merupakan hambatan bagi jalannya pengadilan. Dalam hal ini permasalahannya tidak hanya dalam pemeriksaan di persidangan saja, tetapi juga penyelesaian pada berita acara pemeriksaan di persidangan hingga penandatanganan putusan oleh hakim dan pelaksanaannya. Sering terjadi suatu perkara tertunda sampai bertahun-tahun karena saksi tidak datang, atau para pihak bergantian tidak datang atau memutuskan untuk mundur dari perkara. Bahkan ada beberapa perkara yang dilanjutkan oleh ahli warisnya. Sedangkan dilihat dari segi biaya dalam persidangan, biaya perkara yang tinggi akan menyebabkan pihak yang berkepentingan akan berpikir berkalikali untuk mengajukan tuntutan hak ke pengadilan. Berdasarkan hal tersebut dapat ditarik kesimpulan bahwa, cepatnya jalannya persidangan akan meningkatkan kewibawaan pengadilan tersebut dan menambah kepercayaan masyarakat kepada pengadilan.
\end{abstract}

\begin{abstract}
Legal principles as basic norms are described as the basis / general guidelines for positive law / applicable law. One of the legal principle problems that will be discussed by researchers in this research is about the application of principles that are not in accordance with the reality that occurs in court. There are too many formalities that are difficult to understand, and the rules are not clear, which allows for
\end{abstract}




\section{Jurnal Cakrawala Hukum, Volume 11 No. 3 Desember 2020}

ISSN PRINT 2356-4962 ISSN ONLINE 2598-6538

multiple interpretations and results in fear of proceeding in court. Too many formalities are an obstacle to the running of the courts. In this case the problem is not only in the examination at trial, but also in the settlement of the examination report at the trial until the signing of the decision by the judge and its implementation. It often happens that a case is delayed for years because the witnesses do not come, or the parties in turn do not come or decide to withdraw from the case. In fact, there are several cases that were continued by their heirs. Meanwhile, in terms of costs in court, the high court costs will cause interested parties to think again and again about filing a claim to court. Based on this, it can be concluded that the speed with which the trial runs will increase the court's authority and increase public confidence in the court.

\section{Pendahuluan}

Hubungan antara masyarakat dengan hukum merupakan hubungan yang sangat erat dan tidak dapat dipisahkan antara yang satu dengan yang lain. Keberadaan hukum sebagai pengatur kehidupan masyarakat, sedangkan hukum sebagai tempat/wadah bagi berlakunya suatu aturan. Tidak mungkin ada hukum apabila tidak ada masyarakat. Selain itu tidak dapat dipungkiri bahwa pada kenyataannya hukum juga merupakan salah satu sarana utama bagi masyarakat untuk memenuhi segala kebutuhan/keperluan pokok hidupnya dalam keadaan yang sebaik-baiknya. Hal tersebut dikarenakan hukum memberikan perlindungan atas hak-hak yang dimiliki setiap orang, disamping menetapkan kewajiban-kewajiban yang harus dipenuhi berkenaan dengan hak-hak yang dimilikinya tersebut.

Hukum juga memberi pembatasan atas hakhak seseorang pada batas maksimal dengan tujuan, agar tidak dapat mengganggu dan merugikan hak orang lain, selain itu kewajiban yang harus dipenuhinya demi keseimbangan dan keadilan antara orang yang satu dengan yang lain. Berdasarkan hal tersebut, maka jelaslah bahwa keberadaan hukum di dalam masyarakat bukan hanya menjamin keamanan dan kebebasan saja, tetapi juga ketertiban dan keadilan bagi setiap orang demi memenuhi kebutuhannya, memperjuangkan haknya, dan mencari keadilan.
Pengadilan sebagai tempat terakhir para pencari keadilan untuk memperjuangkan dan mendapatkan kembali hak-haknya berdasarkan alatalat bukti yang akan diajukan oleh para pihak yang berperkara sesuai dengan pasal 164 HIR kepada hakim yang memutus perkara. Kondisi pengadilan di Indonesia saat ini semakin dituntut untuk bisa memberikan pelayanan yang baik bagi para pencari keadilan untuk lebih transparan, akuntabel, dan profesional. Kondisi masyarakat yang semakin global dan berkembang pesat, menuntut pengadilan sebagai lembaga hukum pemutus perkara, untuk terus dapat berinovasi menjadi lembaga pengadilan yang dapat menjawab seluruh permasalahan yang diajukan.

Mengamati perkembangan masyarakat yang begitu pesat, dapat diperkirakan jumlah perkara yang diajukan ke pengadilan negeri seluruh Indonesia mencapai angka ribuan kasus, sehingga Mahkamah Agung sebagai salah satu lembaga kekuasaan kehakiman harus berusaha mereformasi sistem yang berjalan demi mengutamakan pelayanan publik dalam bidang hukum.

Undang-Undang Dasar Negara Republik Indonesia Tahun 1945, dalam bab IX tentang kekuasaan kehakiman pasal 24, menyatakan bahwa kekuasaan kehakiman merupakan kekuasaan yang merdeka yang dilakukan oleh sebuah Mahkamah Agung dan badan peradilan yang berada di bawahnya dalam lingkungan peradilan umum, 


\section{Sistem "full pre trial disclosure" dalam penegakan asas peradilan sederhana, cepat dan biaya ringan}

Wika Yudha Shanty

lingkungan peradilan agama, lingkungan peradilan militer, lingkungan peradilan tata usaha negara, dan oleh sebuah Mahkamah Konstitusi, untuk menyelenggarakan peradilan guna menegakkan hukum dan keadilan.

Kekuasaan kehakiman yang merdeka dan peradilan yang bersih serta berwibawa perlu diwujudkan dengan penataan sistem peradilan yang terpadu. Sejarah perkembangan undang-undang kekuasaan kehakiman dimulai sejak UU No. 19 tahun 1964 tentang ketentuan-ketentuan pokok kekuasaan kehakiman, UU No. 14 tahun 1970 tentang ketentuan-ketentuan pokok kekuasaan kehakiman, UU No. 24 tahun 2004 tentang kekuasaan kehakiman, dan yang sampai sekarang berlaku adalah UU No. 48 tahun 2009 tentang kekuasaan kehakiman yang kesemuaanya memiliki tujuan untuk mewujudkan keadilan, kemanfaatan, dan kepastian hukum.

Perkembangan masyarakat di Indonesia yang berjalan sangat cepat dan dinamis menjadikan waktu menjadi hal primer dan sangat dibutuhkan. Dalam hal ini law as a tools of social engineering, hukum sangat berperan aktif sebagai penentu pergerakan tersebut yang dapat menjamin kepastian hukum, kemanfaatan, dan keadilan. Asas hukum yang diberlakukan dalam sistem hukum acara perdata merupakan pedoman bagi lingkungan peradilan dalam beracara. Asas hukum sebagai norma dasar yang dijabarkan sebagai dasar/petunjuk umum bagi hukum positif/hukum yang berlaku.

Salah satu permasalahan asas hukum yang akan dibahas oleh peneliti dalam penelitian kali ini adalah tentang penerapan asas yang tidak sesuai dengan kenyataan yang terjadi di pengadilan. Terlalu banyak formalitas yang sulit untuk dipahami, dan peraturan-peraturan yang tidak jelas, sehingga memungkinkan timbulnya berbagai penafsiran dan mengakibatkan ketakutan untuk beracara di pengadilan.

Terlalu banyak formalitas merupakan hambatan bagi jalannya pengadilan. Dalam hal ini per- masalahannya tidak hanya dalam pemeriksaan di persidangan saja, tetapi juga penyelesaian pada berita acara pemeriksaan di persidangan hingga penandatanganan putusan oleh hakim dan pelaksanaannya. Sering terjadi suatu perkara tertunda sampai bertahun-tahun karena saksi tidak datang, atau para pihak bergantian tidak datang atau memutuskan untuk mundur dari perkara. Bahkan ada beberapa perkara yang dilanjutkan oleh ahli warisnya.

Sedangkan dilihat dari segi biaya dalam persidangan, biaya perkara yang tinggi akan menyebabkan pihak yang berkepentingan akan berpikir berkali-kali untuk mengajukan tuntutan hak ke pengadilan. Berdasarkan hal tersebut dapat ditarik kesimpulan bahwa, cepatnya jalannya persidangan akan meningkatkan kewibawaan pengadilan tersebut dan menambah kepercayaan masyarakat kepada pengadilan.

Selain hal tersebut, yang menjadi permasalahan dalam sistem peradilan di Indonesia adalah panjangnya liku-liku persidangan yang harus dilalui para pencari keadilan.

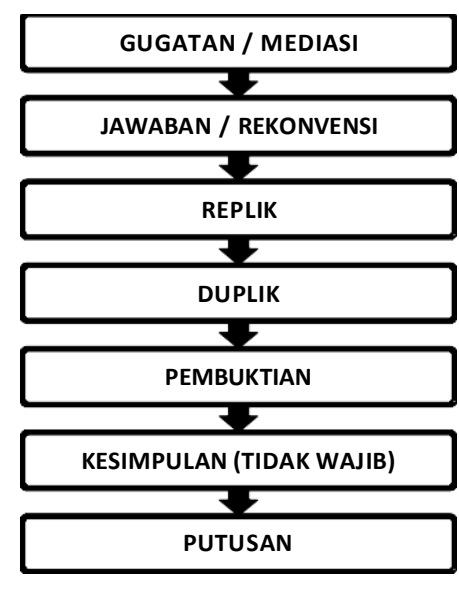

Tahap Yudisial

Dalam beberapa kasus, tahapan yudisial seperti yang ada dalam bagan tersebut, pada tahap replik dan duplik harus ditambahkan tahap rereplik dan re-duplik. Kemudian, pada tahap pem- 


\section{Jurnal Cakrawala Hukum, Volume 11 No. 3 Desember 2020}

ISSN PRINT 2356-4962 ISSN ONLINE 2598-6538

buktian baik penggugat/pemohon maupun tergugat/termohon diwajibkan menghadirkan alatalat bukti yang dapat mendukung pernyataannya baik di dalam gugatan maupun di dalam jawabannya.

Apabila hal tersebut disandingkan dengan sistem menejemen peradilan full pre trial disclosure, dimana sistem tersebut adalah sistem yang diajukan panitia yang diketuai oleh Lord Hailsman. Sistem ini mencoba menggabungkan/mengintegrasikan menejemen ke dalam sistem peradilan. Permasalahan yang akan dibahas adalah penerapan sistem full pre trial disclosure dalam sistem hukum peradilan di Indonesia, dan kesulitan dalam mengintegrasikan sistem full pre trial disclosure dalam sistem hukum peradilan di Indonesia.

\section{Metode}

Penelitian ini merupakan penelitian deskriptif yang bersifat eksploratif, yaitu suatu penelitian yang bertujuan untuk menggambarkan keadaan atau status dari fenomena. (Arikunto 1989). Atas dasar itu maka teknik analisa yang dipergunakan adalah content analisys, yaitu analisa berdasarkan isi dari bahan hukum. Hal ini mengingat bahan hukum yang ada bersifat deskriptif.

\section{Pembahasan}

\section{1. penerapan sistem full pre trial disclo- sure dalam sistem hukum peradilan di Indonesia}

Undang-undang Nomor 48 tahun 2009 tentang Kekuasaan Kehakiman, pada Pasal 2 ayat (4) menyebutkan bahwa peradilan dilakukan dengan sederhana, cepat, dan biaya ringan. Asas sederhana, cepat dan biaya ringan adalah asas peradilan yang paling mendasar dari pelaksanaan dan pelayanan administrasi peradilan yang mengarah pada prinsip dan asas efektif dan efisien (Sunaryo, 2005).
Asas sederhana adalah pemeriksaan dan penyelesaian perkara dilakukan dengan cara efesien dan efektif (Penjelasan Pasal 2 ayat (4) UU No.48 Tahun 2009). Sederhana juga dapat dimaknai sebagai suatu proses yang tidak berbelit-belit, tidak rumit, jelas, lugas, non interpretable, mudah dipahami, mudah dilakukan, mudah diterapkan, sistematis, konkrit baik dalam sudut pandang pencari keadilan, maupun dalam sudut pandang penegak hukum yang mempunyai tingkat kualifikasi yang sangat beragam, baik dalam bidang potensi pendidikan yang dimiliki, kondisi sosial ekonomi, budaya dan lain-lain. (Sunaryo, 2005)

Asas cepat bermakna bahwa persidangan perdata harus diselenggarakan dalam tenggang waktu tertentu yang patut. (Asnawi, 2016) Hal lain yang perlu dipertimbangkan dalam penerapan dari asas ini adalah apabila dilakukan penundaan sidang harus mempertimbangkan aspek kepatutan dari segi tata urutan beracara dan dari segi waktu beracara dalam suatu perkara perdata. Penundaan persidangan dengan tenggat waktu yang jauh melebihi kepatutan dan/atau dengan alasan yang tidak dibenarkan oleh hukum merupakan sesuatu yang tidak dibenarkan.

Salah satu peraturan yang merupakan implementasi dari asas cepat dapat dilihat dalam pasal 159 ayat (1) HIR/186 ayat (1) R.Bg yang menyatakan: "Jika suatu perkara tidak dapat diselesaikan pada hari persidangan pertama, yang ditetapkan untuk memeriksanya, maka pemeriksaan perkara itu diundurkan untuk melanjutkan sampai hari persidangan lain, yang sedapat-dapatnya tidak berapa lama kemudian, dan demikian juga seterusnya." (Syahrani, 1991)

Pasal ini menentukan pengunduran persidangan pada hari yang akan datang, apabila pemeriksaan perkara itu tidak selesai dalam sidang pertama. Hal tersebut harus dilakukan sampai pemeriksaan perkara dapat diselesaikan. Asas biaya ringan merupakan asas yang menyatakan bahwa biaya yang timbul dari perkara yang diajukan ke pengadilan harus ditentukan dengan 


\section{Sistem "full pre trial disclosure" dalam penegakan asas peradilan sederhana, cepat dan biaya ringan}

Wika Yudha Shanty

biaya yang layak, sesuai, dan sebisa mungkin dapat dijangkau oleh berbagai lapisan masyarakat.

Asas biaya ringan ini juga berkaitan dengan access to justice, yaitu dalam hal ini memberikan kesempatan seluas-luasnya untuk masyarakat pencari keadilan (justitiabelen) untuk bisa mengakses pengadilan dan memperjuangkan haknya. Penerapan dari asas ini dapat dilihat dalam pasal 182 HIR/192 R.Bg yang isinya sebagai berikut: "Hukuman membayar biaya itu dapat meliputi tidak lebih dari: a. biaya kantor panitera dan biaya meterai, yang perlu dipakai dalam perkara itu; b. biaya saksi, orang ahli dan juru bahasa terhitung juga biaya sumpah mereka itu, dengan pengertian bahwa fihak yang meminta supaya diperiksa lebih dari lima orang saksi tentang satu kejadian itu, tidak dapat memperhitungkan bayaran kesaksian yang lebih itu kepada lawannya; c. biaya pemeriksaan setempat dan perbuatan hakim dan lainlain; d. gaji pegawai yang disuruh melakukan panggilan, pemberitahuan dan segala surat jurusita yang lain; $e$. biaya yang tersebut pada pasal 138, ayat keenam; f. gajih yang harus dibayar kepada panitera atau pegawai lain karena menjalankan keputusan." (Fakhriah, 2015)

Pasal tersebut menetapkan biaya-biaya yang dikenakan kepada pihak yang mengajukan perkaranya ke pengadilan. Diluar biaya yang telah disebutkan diatas, sepanjang tidak diatur dalam peraturan lainnya, maka tidak dibenarkan dibebankan kepada para pihak.

Menurut The Liang Gie, manajemen adalah suatu proses penggerakan tindakan-tindakan dan penggerakan fasilitas-fasilitas serta usaha kerja sama agar tujuan yang telah ditentukan benarbenar tercapai. (Arto, 2017) Sejalan dengan pendapat Prof. Dr. Prajudi Atmosudirjo yang mengatakan bahwa manajemen itu adalah pengendalian dan pemanfaatan semua faktor dan sumber daya yang menurut suatu perencanaan (planning) diperlukan untuk mencapai atau menyelesaikan suatu prapta (tujuan) kerja tertentu. (Arto, 2017)

Berdasarkan hal tersebut, maka dapat dijelaskan secara luas bahwa manajemen penyelesaian perkara merupakan suatu keterampilan yang untuk mengendalikan, menggerakkan, dan memanfaatkan semua unsur dan sumber daya yang ada dalam peradilan yang diperlukan untuk menyelesaikan perkara secara efektif, efisien, tepat, tuntas, final, dan memberikan rasa keadilan bagi masyarakat.

Konsep full pre trial disclosure pertama kali diajukan pada tahun 1985 oleh suatu panitia yang diketuai oleh Lord Hailsham. Tujuan dibentuknya konsep ini adalah untuk menggabungkan dan mengitegrasikan sistem manajemen peradilan. Salah satu pokok pikiran yang muncul adalah konsep tentang Full Pre-trial Disclosure. (Harahap, 2006)

Dalam konsep ini, sistem peradilan yang panjang dan berbelit-belit bisa disederhanakan dengan cara, pada saat mengajukan gugatan, penggugat harus sekaligus melengkapi atau melampirkan alat bukti sebagai pelengkap gugatannya. Begitu juga pada saat tergugat mengajukan jawaban, harus sekaligus dengan pembuktian sebagai pelengkap jawabannya. Melalui sistem seperti ini maka, tahap proses pembuktian dipersingkat. Dalam sistem ini, sebelum sidang dimulai, hakim sudah mempelajari dan mendalami perkara secara keseluruhan. Persidangan cukup memeriksa halhal tertentu saja, tidak lagi bertele-tele memasuki tahap replik dan duplik.

Dalam sejarahnya, sistem hukum Indonesia terbentuk dan dipengaruhi oleh 3 sub sistem hukum yaitu, 1). Sistem hukum barat; sistem ini merupakan warisan penjajah kolonial Belanda yang bersistem individualistik. Peninggalan hasil ciptaan bangsa Belanda sampai saat ini masih banyak yang tetap diberlakukan, seperti misalnya WetBoek Van Strafrecht Voor Nederlandsch-Indie/Kitab Undangundang Hukum Pidana (KUHP) yang pengesahannya dilakukan melalui staatsblad tahun 1915 nomor 732 dan mulai belaku sejak tanggal 1 Januari 1918, dan Burgerlijk Wetboek/Kitab Undang-undang Hukum Acara Perdata (K.U.H. Perdata) yang besumber dari hukum Napoleon, berdasarkan 


\section{Jurnal Cakrawala Hukum, Volume 11 No. 3 Desember 2020}

ISSN PRINT 2356-4962 ISSN ONLINE 2598-6538

staatblad nomor 23 tahun 1847. Kodifikasi Kitab Undang-undang Hukum Acara Perdata (K.U.H. Perdata) diumumkan pada tanggal 30 April 1847 melalui staatblad nomor 23 dan berlaku Januari 1848. 2). Sistem hukum adat; sistem ini bersifat komunal atau kemasyarakatan artinya bahwa kehidupan manusia selalu dilihat dalam wujud kelompok sebagai satu kesatuan yang utuh, individu satu sama lain tidak dapat hidup sendiri. Manusia adalah mahluk sosial, membutuhkan orang lain, manusia selalu hidup bermasyarakat, kepentingan bersama selalu diutamakan dari kepentingan perseorangan maupun golongan. 3). Sistem hukum Islam; sistem hukum ini bersifat religius yang bersumber kepada kitab suci Al Quran, sunnah nabi, Ijma, dan Qiyas. Pengakuan hukum Islam seperti Regeling Reglement, dimulai sejak tahun 1855, membuktikan bahwa keberadaan hukum Islam sebagai salah satu sumber hukum Indonesia berdasarkan teori "Receptie"

Sistem Peradilan Indonesia dapat ditelusuri dari ketentuan Pasal 24 Ayat (2) Undang-undang Dasar Negara Republik Indonesia tahun 1945 yang menyatakan bahwa: "kekuasaan kehakiman tidak hanya dilakukan oleh sebuah Mahkamah Agung tetapi juga oleh sebuah mahkamah konstitusi"; dan pasal 18 Undang-undang Nomor 48 Tahun 2009 Tentang Kekuasaan Kehakiman yang menyatakan bahwa "Kekuasaan kehakiman dilakukan oleh sebuah Mahkamah Agung dan badan peradilan yang berada di bawahnya dalam lingkungan peradilan umum, lingkungan peradilan agama, lingkungan peradilan militer, dan lingkungan peradilan tata usaha negara, serta oleh sebuah Mahkamah Konstitusi".

Undang-undang Nomor 48 Tahun 2009 Tentang Kekuasaan Kehakiman, pada pasal 27 ayat (1) menyatakan bahwa "Pengadilan khusus hanya dapat dibentuk dalam salah satu lingkungan peradilan yang berada di bawah Mahkamah Agung sebagaimana dimaksud dalam Pasal 25".
Berdasarkan penjelasan pasal 27 Ayat (1) Undang-undang Nomor 48 Tahun 2009 Tentang Kekuasaan Kehakiman, yang dimaksud dengan "pengadilan khusus" antara lain adalah pengadilan anak, pengadilan niaga, pengadilan hak asasi manusia, pengadilan tindak pidana korupsi, pengadilan hubungan industrial dan pengadilan perikanan yang berada di lingkungan peradilan umum, serta pengadilan pajak yang berada di lingkungan peradilan tata usaha negara.

Pasal 25 Undang-undang Nomor 48 Tahun 2009 Tentang Kekuasaan Kehakiman membagi badan-badan peradilan yang berada di bawah Mahkamah Agung yang meliputi, 1). Peradilan umum sebagaimana dimaksud pada ayat (1) berwenang memeriksa, mengadili, dan memutus perkara pidana dan perdata sesuai dengan ketentuan peraturan perundang-undangan. 2). Peradilan agama sebagaimana dimaksud pada ayat (1) berwenang memeriksa, mengadili, memutus, dan menyelesaikan perkara antara orang-orang yang beragama Islam sesuai dengan ketentuan peraturan perundang-undangan. 3). Peradilan militer sebagaimana dimaksud pada ayat (1) berwenang memeriksa, mengadili, dan memutus perkara tindak pidana militer sesuai dengan ketentuan peraturan perundang-undangan. 4). Peradilan tata usaha negara sebagaimana dimaksud pada ayat (1) berwenang memeriksa, mengadili, memutus, dan menyelesaikan sengketa tata usaha negara sesuai dengan ketentuan peraturan perundangundangan.

Tugas Mahkamah Konstitusi adalah: 1) Menguji Undang-Undang terhadap UUD 1945. 2) Memutus sengketa kewenangan Lembaga Negara yang kewenangannya diberi oleh UUD 1945. 3) Memutus Pembubaran Partai Politik. 4) Memutus perselisihan tentang PEMILU. 5) Memberikan putusan atas pendapat DPR tentang dugaan Presiden/Wakil Presiden melanggar hukum, berupa: mengkhianati negara, korupsi, suap, tin- 


\section{Sistem "full pre trial disclosure" dalam penegakan asas peradilan sederhana, cepat dan biaya ringan \\ Wika Yudha Shanty}

dak pidana berat lainnya, atau perbuatan tercela lainnya.

Fungsi utama peradilan dalam aspek peradilan perdata adalah "the primary function of the court is to determine the legality of various kind of behaviour". Selain menentukan keabsahan berbagai jenis perilaku masyarakat (mengadili), peradilan juga berfungsi memberi nasehat, mengatur, dan menguji materiil. (Diantha, 2000)

Fungsi peradilan dalam perkara perdata harus berlandaskan asas/prinsip hukum kekuasaan kehakiman, antara lain yaitu asas/prinsip hukum acara sederhana, cepat, dan biaya murah.

Asas/prinsip hukum peradilan sederhana, cepat, dan biaya ringan merupakan asas/prinsip hukum yang penting karena prinsip ini merupakan prinsip yang mendasari semua tahap peradilan. Mulai dari peradilan tingkat pertama, peradilan tingkat banding, sampai pada tingkat Mahkamah Agung. Tiga aspek yang melandasi asas ini yaitu sederhana, cepat, dan biaya ringan.

Asas tersebut dijabarkan dalam pasal 2 ayat 4 Undang-undang Nomor 48 Tahun 2009 Tentang Kekuasaan Kehakiman yang menyatakan bahwa: "Peradilan dilakukan dengan sederhana, cepat, dan biaya ringan." Sedangkan penjelasan tentang asas tersebut berdasarkan penjelasan pasal 2 ayat (4) Undang-undang Nomor 48 Tahun 2009 Tentang Kekuasaan Kehakiman yaitu:" Yang dimaksud dengan "sederhana" adalah pemeriksaan dan penyelesaian perkara dilakukan dengan cara efesien dan efektif. Yang dimaksud dengan "biaya ringan" adalah biaya perkara yang dapat dijangkau oleh masyarakat. Namun demikian, asas sederhana, cepat, dan biaya ringan dalam pemeriksaan dan penyelesaian perkara di pengadilan tidak mengesampingkan ketelitian dan kecermatan dalam mencari kebenaran dan keadilan."

Kembali kepada sistem manajemen peradilan full pre trial disclosure, dimana mengusulkan untuk memadukan unsur-unsur sistem manajemen ke dalam hukum acara perdata dengan harapan akan terwujud suatu sistem peradilan yang efisien dan produktif, dengan cara pada saat penggugat mengajukan gugatan harus bersamaan dengan pengajuan bukti-bukti, termasuk keterangan saksisaksi (witness statements). Begitu juga pasa saat tergugat mengajukan jawaban harus pula bersamaan dengan pengajuan bukti-bukti, berikut juga dengan keterangan saksi-saksi.

Manajemen adalah ilmu yang sangat berguna dan cukup fleksibel ntuk setiap usaha manusia untuk mencapai tujuan secara efektif, efisien, dan memuaskan. Dengan penerapan ilmu manajemen modern pengadilan akan menjadi mitra kerja masyarakat modern. (Arto, 2017)

Dalam hal ini unsur-unsur manajemen sangan cocok dan sangat diperlukan dalam menjalankan proses menyelesaian perkara perdata, alasannya yaitu dengan adanya penerapan asas tersebut maka asas-asas dalam hukum acara perdata hanya dapat direalisasikan dalam praktek persidangan apabila prinsip manajemen tersebut benar-benar diterapkan dalam praktek penyelesaian perkara.

Gugatan Sederhana atau Small Claim Court adalah tata cara pemeriksaan di persidangan terhadap gugatan perdata dengan nilai gugatan materil maksimal sebanyak Rp. 200.000.000,00 (Dua Ratus Juta Rupiah), yang diselesaikan dengan tata cara dan pembuktian sederhana. Yang membedakan gugatan sederhana dengan gugatan ada umumnya adalah nilai kerugian materiil yang lebih khusus ditentukan pada gugatan sederhana, yakni maksimal Rp.200.000.000,00 (Dua Ratus Juta Rupiah). Sedangkan pada gugatan pada perkara perdata biasa, nilai kerugian materiil tidak dibatasi besarnya.

Dalam Pasal 4 ayat (4) Peraturan Mahkamah Agung nomor 2 tahun 2015 ada frasa "dengan atau tanpa didampingi oleh kuasa hukum". Jadi, para pihak boleh pakai jasa advokat atau tidak. Tetapi, kalau penggugat/tergugatnya pakai jasa advokat bisa rugi karena dikhawatirkan nilai gugatannya tidak sebanding dengan biaya jasa advokat yang 


\section{Jurnal Cakrawala Hukum, Volume 11 No. 3 Desember 2020}

ISSN PRINT 2356-4962 ISSN ONLINE 2598-6538

dikeluarkan.

Tahapan dalam penyelesaian gugatan sederhana yaitu: gugatan sederhana diperiksa dan diputus oleh Hakim tunggal yang ditunjuk oleh Ketua Pengadilan; Tahapan penyelesaian gugatan sederhana meliputi: pendaftaran, pemeriksaan kelengkapan gugatan sederhana, penetapan Hakim dan penunjukan panitera pengganti, pemeriksaan pendahuluan, penetapan hari sidang dan pemanggilan para pihak, pemeriksaan sidang dan perdamaian, pembuktian, dan terakhir adalah tahap putusan.

Penyelesaian gugatan sederhana paling lama 25 (dua puluh lima) hari sejak hari sidang pertama. Dalam Peraturan Mahkamah Agung nomor 2 tahun 2015, maka Pemeriksaan Pendahuluan menjadi tahapan paling krusial karena di tahap ini, hakim berwenang menilai dan kemudian menentukan apakah perkara tersebut adalah gugatan sederhana. Dalam Pemeriksaan Pendahuluan, apabila dalam pemeriksaan Hakim berpendapat bahwa gugatan tidak termasuk dalam gugatan sederhana, maka Hakim mengeluarkan penetapan yang menyatakan bahwa gugatan bukan gugatan sederhana, mencoret dari register perkara dan memerintahkan pengembalian sisa biaya perkara kepada penggugat.

Pada putusan akhir gugatan sederhana, para pihak diberikan kesempatan untuk mengajukan keberatan paling lambat 7 (tujuh) hari setelah putusan diucapkan atau setelah pemberitahuan putusan. Keberatan ini diputus majelis hakim sebagai putusan akhir, sehingga tidak tersedia upaya hukum banding, kasasi, atau peninjauan kembali.

Dengan adanya Peraturan Mahkamah Agung nomor 2 tahun 2015, maka hal ini adalah suatu langkah besar bagi Indonesia untuk menegakkan asas peradilan sederhana, cepat, dan biaya ringan. Penerapan sistem manajemen peradilan full pre trial disclosure secara tidak langsung berjalan dan terintegrasi dengan baik karena pada Peraturan Mahkamah Agung ini para pihak diberi batasan waktu yaitu 25 hari untuk menyelesaikan perkaranya. Dengan demikian para pihak yang bersengketa harus melengkapi berkas gugatan dan pembuktiannya.Namun Peraturan Mahkamah Agung ini masih dibatasi oleh jumlah nilai gugatan sehingga tidak semua perkara dapat diselesaikan melalui sistem ini.

\subsection{Kesulitan dalam mengintegrasikan sistem full pre trial disclosure dalam sistem hukum peradilan di Indonesia}

Kecenderungan dan ciri masyarakat modern antara lain menginginkan segala sesuatunya bersifat praktis, efektif, efisien, dan memuaskan. Ditambah lagi dengan berbagai kegiatan dan usaha yang semakin beraneka ragam dan persaingan yang ketat. (Maulidiyah, 2019) Untuk mencapai kesuksesan tersebut, mereka membutuhkan suatu manajemen modern yang sesuai dengan kebutuhan dan perkembangan masyarakat. Masyarakat modern selalu menerapkan manajemen modern sebagai ciri khasnya. Persaingan usaha yang semakin ketat, berbenturan dengan kepentingan dan perebutan sumber-sumber pemenuhan kebutuhan dalam masyarakat, itulah yang sering menimbulkan konflik/sengketa di antara mereka. Konflik atau sengketa itu memerlukan penyelesaian yang efektif, efisien, dan memuaskan.

Indonesia adalah negara hukum (rechtsaat), untuk menentukan suatu negara adalah negara hukum, tolak ukurnya adalah ciri negara hukum dimuat dalam konstitusi. (Hamzah, 2013) Undangundang Dasar Negara Republik Indonesia tahun 1945 dalam alenia ke-4 pembukaan menyatakan bahwa, “...maka disusunlah kemerdekaan kebangsaan Indonesia itu dalam suatu Undangundang Dasar Negara Indonesia...". Jadi RI ialah suatu negara hukum yang berkonstitusi yang dituliskan. (Yamin, 1952)

Pembuat Undang-undang Dasar Negara Republik Indonesia tahun 1945 menempatkan kons- 


\section{Sistem "full pre trial disclosure" dalam penegakan asas peradilan sederhana, cepat dan biaya ringan}

Wika Yudha Shanty

titusi sebagai sumber dari pengaturan tentang segala urusan yang berhubungan dengan kenegaraan. Hal ini merupakan suatu bukti bahwa adanya keinginan pembentuk negara untuk mewujudkan Indonesia sebagai negara hukum.

Indonesia sebagai negara hukum (rechtstaat) yang tunduk pada asas rule of law, dimana kedudukan peradilan dianggap sebagai pelaksana judicial power (kekuasaan kehakiman). (Sunarjo, 2014) Pengadilan masih tetap relevan sebagai last resort (tempat terakhir) dalam pencarian kebenaran dan keadilan, sehingga pengadilan masih diandalkan sebagai badan yang berfungsi dan berperan to enforce the thruth and justice (menegakkan keadilan dan kebenaran). Maka dengan demikian pengadilan mempunyai peran sebagai pressure valve (penekan) atas segala pelanggaran hukum dan ketertiban masyarakat.

Karakter pada tatanan operasional konsep negara hukum (rechtstaat) yaitu: Adanya perlindungan terhadap hak asasi manusia (HAM); Adanya pemisahan dan pembagian kekuasaan negara untuk menjamin perlindungan hak asasi manusia (HAM); Pemerintah berdasarkan peraturan; dan Adanya peradilan administrasi. (Hamzah, 2000)

Seiring dengan berjalannya waktu, banyak sekali ditemukan permasalahan yang sangat mengganggu berjalannya sistem peradilan di masyarakat. Hal tersebut tidak hanya berimbas kepada negara, namun juga membawa dampak yang tidak baik bagi masyarakat. Berjalannya peradilan yang tidak efektif dan tidak efisien merupakan salah satu contoh penyelesaian perkara yang pada akhirnya memakan waktu yang sangat panjang bahkan bertahun-tahun lamanya.

Proses peradilan yang kompleks dan berputar-putar pada upaya hukum yang panjang. Dimulai dari upaya banding, upaya kasasi, dan upaya peninjauan kembali. Bahkan setelah putusan yang sudah berkekuatan hukum sekali pun, eksekusi berbenturan pula dengan upaya verzet. Dengan kata lain, proses tersebut seakan-akan tidak berujung.

Memasuki gelanggang forum pengadilan, tidak ubahnya mengembara dan mengadu nasib di hutan belantara (adventure unto the unknown). Padahal masyarakat pencari keadilan membutuhkan proses penyelesaian yang cepat yang tidak formalistis atau informal procedure and can be put into motion quickly. (Harahap, 1997)

Sistem manajemen dalam peradilan pernah diajukan oleh suatu panitia yang diketuai oleh seorang berkebangsaan Inggris bernama Lord Hailsham dari St. Marylebone, seorang politisi Konservatif Inggris terkemuka yang bertugas di enam pemerintahan, termasuk administrasi perang Churchill, dan merupakan kanselir penguasa paling lama, atau kepala peradilan Inggris, pada abad ke-20. Salah satu sistem manajemen yang pernah diajukan adalah sistem manajemen peradilan full pre trial disclosure. Sistem ini mengusulkan untuk memadukan unsur-unsur sistem manajemen ke dalam sistem peradilan perdata. Dengan mengaplikasikan sistem ini diharapkan akan terwujud suatu sistem peradilan yang efisien dan produktif. Sistem ini bekerja dengan cara pada saat penggugat mengajukan gugatan harus bersamaan dengan pengajuan bukti-bukti, termasuk keterangan saksisaksi (witness statements). Begitu juga pasa saat tergugat mengajukan jawaban harus pula bersamaan dengan pengajuan bukti-bukti, berikut juga dengan keterangan saksi-saksi.

Dalam prakteknya, tidak hanya di Indonesia, akan tetapi di negara manapun belum ada yang mampu untuk mendesain sistem peradilan yang efektif dan efisien. Hal tersebut sulit dikarenakan terlalu banyak aspek yang saling bertentangan antara yang satu dengan yang lain. Sebagai contoh, misalnya ada kepentingan lain yang harus dilindungi, sedangkan di sisi lain kepentingan itu bertentangan dengan kepentingan yang lain. Pada satu sisi, harus dibuat sistem yang mamppu melindungi 


\section{Jurnal Cakrawala Hukum, Volume 11 No. 3 Desember 2020}

ISSN PRINT 2356-4962 ISSN ONLINE 2598-6538

kepentingan penggugat. Di sisi lain, harus pula diberi perlindungan kepada tergugat yang mengalami kekalahan untuk mengajukan upaya hukum berupa banding dan kasasi.

Satu contoh pula yang sering terjadi dalam persidangan. Pada saat penggugat yang memenangkan perkaranya di pengadilan negeri sangat menginginkan putusan untuknya tersebut langsung mempunyai kekuatan hukum tetap yang final and binding, sehingga dalam waktu cepat putusan tersebut dapat dijalankan dan dieksekusi. Pihak yang menang tersebut sangat menginginkan ditutupnya segala bentuk upaya hukum yang ada. Akan tetapi, apabila keadaan tersebut dibalik, dimana pihak penggugat yang mengalami kekalahan dalam perkara tersebut, maka apakah pihak penggugat akan menerima kekalahannya dan juga menerima bahwa ia tidak mempunyai upaya hukum apapun untuk melawan putusan tersebut? Pihak penggugat yang kalah tersebut pasti mengangap bahwa hak-haknya disalahi oleh tergugat, bahkan pihak penggugat menganggap ada diskriminasi yang terjadi dalam proses persidangan tersebut.

Semakin panjangnya waktu persidangan yang juga berbelit-belit, bahkan ada yang mengusulkan agar pemeriksaan tingkat banding dilakukan langsung sebagaimana sistem pemeriksaan di pengadilan negeri. Bukankah hal ini lebih menjerumuskan sistem peradilan semakin tidak efektif?

\section{Simpulan}

Sistem peradilan yang diusulkan oleh Lord Hailsman, diharapkan dapat mengatasi kesulitan dan kelemahan dari sistem peradilan yang panjang dan berbelit-belit. Sistem ini diharapkan bisa disederhanakan dengan cara, pada saat mengajukan gugatan, penggugat harus sekaligus melengkapi atau melampirkan alat bukti sebagai pelengkap gugatannya. Begitu juga pada saat tergugat mengajukan jawaban, harus sekaligus dengan pembuktian sebagai pelengkap jawabannya. Melalui sistem seperti ini maka, tahap proses pembuktian dipersingkat. Dalam sistem ini, sebelum sidang dimulai, hakim sudah mempelajari dan mendalami perkara secara keseluruhan. Persidangan cukup memeriksa hal-hal tertentu saja, tidak lagi berteletele memasuki tahap replik dan duplik.

Dalam prakteknya, tidak hanya di Indonesia, akan tetapi di negara manapun belum ada yang mampu untuk mendesain sistem peradilan yang efektif dan efisien. Hal tersebut sulit dikarenakan terlalu banyak aspek yang saling bertentangan antara yang satu dengan yang lain. Sebagai contoh, misalnya ada kepentingan lain yang harus dilindungi, sedangkan di sisi lain kepentingan itu bertentangan dengan kepentingan yang lain. Pada satu sisi, harus dibuat sistem yang mamppu melindungi kepentingan penggugat. Di sisi lain, harus pula diberi perlindungan kepada tergugat yang mengalami kekalahan untuk mengajukan upaya hukum berupa banding dan kasasi. Peraturan Mahkamah Agung nomor 2 tahun 2015, maka hal ini adalah suatu langkah besar bagi Indonesia untuk menegakkan asas peradilan sederhana, cepat, dan biaya ringan. Penerapan sistem manajemen peradilan full pre trial disclosure secara tidak langsung berjalan dan terintegrasi dengan baik.

\section{Daftar pustaka}

Arto, H.A. Mukti. 2017. Teori dan Seni Menyelesaikan Perkara Perdata di Pengadilan. Kencana. Jakarta.

Asnawi. M. Natsir. 2016. Hukum Acara Perdata Teori Praktek dan Permasalahannya di Peradilan Umum dan Peradilan Agama. UII Persss. Yogyakarta.

Butarbutar, E. N. 2009. Konsep keadilan dalam sistem peradilan perdata. Mimbar Hukum-Fakultas Hukum Universitas Gadjah Mada, 21(2), 354-369.

Diantha, I Md Pasek. 2000. Batas Kebebasan Kekuasaan Kehakiman. Disertasi Program Pasca Sarjana Universitas Airlangga. Surabaya.

Fakhriah, Efa Laela. 2015. Perbandingan HIR dan R.Bg. Sebagai Hukum Acara Perdata Positif di Indonesia. Keni Media. Bandung. 


\section{Sistem "full pre trial disclosure" dalam penegakan asas peradilan sederhana, cepat dan biaya ringan}

Wika Yudha Shanty

Fakhriah, E. L. 2013. Mekanisme Small Claims Cortt Dalam Mewujudkan Tercapainya Peradilan Sederhana, Cepat, Dan Biaya Ringan. Mimbar Hukum-Fakultas Hukum Universitas Gadjah Mada, 25(2), 258-270.

Hamzah, Moh. Amir. 2013. Hukum Acara Perdata Peradilan Tingakt Banding. Setara Perss, Malang.

Harahap, M. Yahya. 2006. Hukum Acara Perdata tentang gugatan, persidangan, penyitaan, pembuktian, dan putusan pengadilan. Sinar Grafika. Jakarta.

Harahap M. Yahya. 1997. Beberapa Tinjauan Mengenai Sistem Peradilan dan Penyelesaian Sengketa. Sinar Grafika. Jakarta.

Maulidiyah, N. and Satriana, Y.N., 2019. Eksistensi Digital Evidence dalam Hukum Acara Perdata. Jurnal Cakrawala Hukum, 10(1), pp.69-76.

Russel, Frances. Locke, Christine. 1992. English Law and Language, Cassel, London.
Sunarjo, S., 2014. Peradilan Sebagai Pilar Negara Hukum Dalam Perspektif Pancasila. Jurnal Cakrawala Hukum, 19(1), pp.71-81.

Sunaryo, Sidik. 2005. Kapita Selekta Sistem Peradilan Pidana. UMM Press. Malang.

Sugiarto, T., 2013. Peranan komisi pemberantasan korupsi (KPK) dalam pemberantasan tindak pidana korupsi di Indonesia. Jurnal Cakrawala Hukum, 18(2).

Syahrani, Riduan. 1991. Himpunan Peraturan Hukum Acara Perdata Indonesia. Alumni. Bandung.

Wantu, F. M. 2011. Peranan Hakim Dalam Mewujudkan Kepastian Hukum Keadilan dan Kemanfaatan di Peradilan Perdata. Doctoral dissertation. PROGRAM PASCASARJANA FAKULTAS HUKUM UNIVERSITAS GADJA. Yogjakarta. 